Bioorg Med Chem Lett. 2009 September 15; 19(18): 5482-5485. doi:10.1016/j.bmcl.2009.07.080.

\title{
Discovery of diarylpyridine derivatives as novel non-nucleoside HIV-1 reverse transcriptase inhibitors
}

\author{
Xingtao Tian ${ }^{a}$, Bingjie Qinn ${ }^{a}$, Hong Lu ${ }^{b}$, Weihong Laid, Shibo Jiang ${ }^{b}$, Kuo-Hsiung Lee ${ }^{c}$, Chin \\ Ho Chend, and Lan Xie ${ }^{a,{ }^{*}}$ \\ aBeijing Institute of Pharmacology \& Toxicology, 27 Tai-Ping Road, Beijing, 100850, China \\ bLindsley F. Kimball Research Institute, New York Blood Center, New York, NY 10065, USA \\ cNatural Products Research Laboratories, Eshelman School of Pharmacy, University of North \\ Carolina, Chapel Hill, NC 27599 , USA \\ dDuke University Medical Center, Box 2926, Surgical Oncology Research Facility, Durham, NC \\ 27710, USA
}

\begin{abstract}
Two series (4 and $\mathbf{5}$ ) of diarylpyridine derivatives were designed, synthesized, and evaluated for antiHIV-1 activity. The most promising compound, 5e, inhibited HIV-1 IIIB, NL4-3, and RTMDR1 with low nanomolar $\mathrm{EC}_{50}$ values and selectivity indexes of $>10,000$. The results of this study indicate that diarylpyridine can be used as a novel scaffold to derive a new class of potent NNRTIs, active against both wild-type and drug resistant HIV-1 strains.
\end{abstract}

(c) 2009 Elsevier Ltd. All rights reserved.

*Corresponding author, lanxieshi@yahoo.com, (L. Xie); Tel/Fax: 86-10-6931690.

Publisher's Disclaimer: This is a PDF file of an unedited manuscript that has been accepted for publication. As a service to our customers we are providing this early version of the manuscript. The manuscript will undergo copyediting, typesetting, and review of the resulting proof before it is published in its final citable form. Please note that during the production process errors may be discovered which could affect the content, and all legal disclaimers that apply to the journal pertain. 


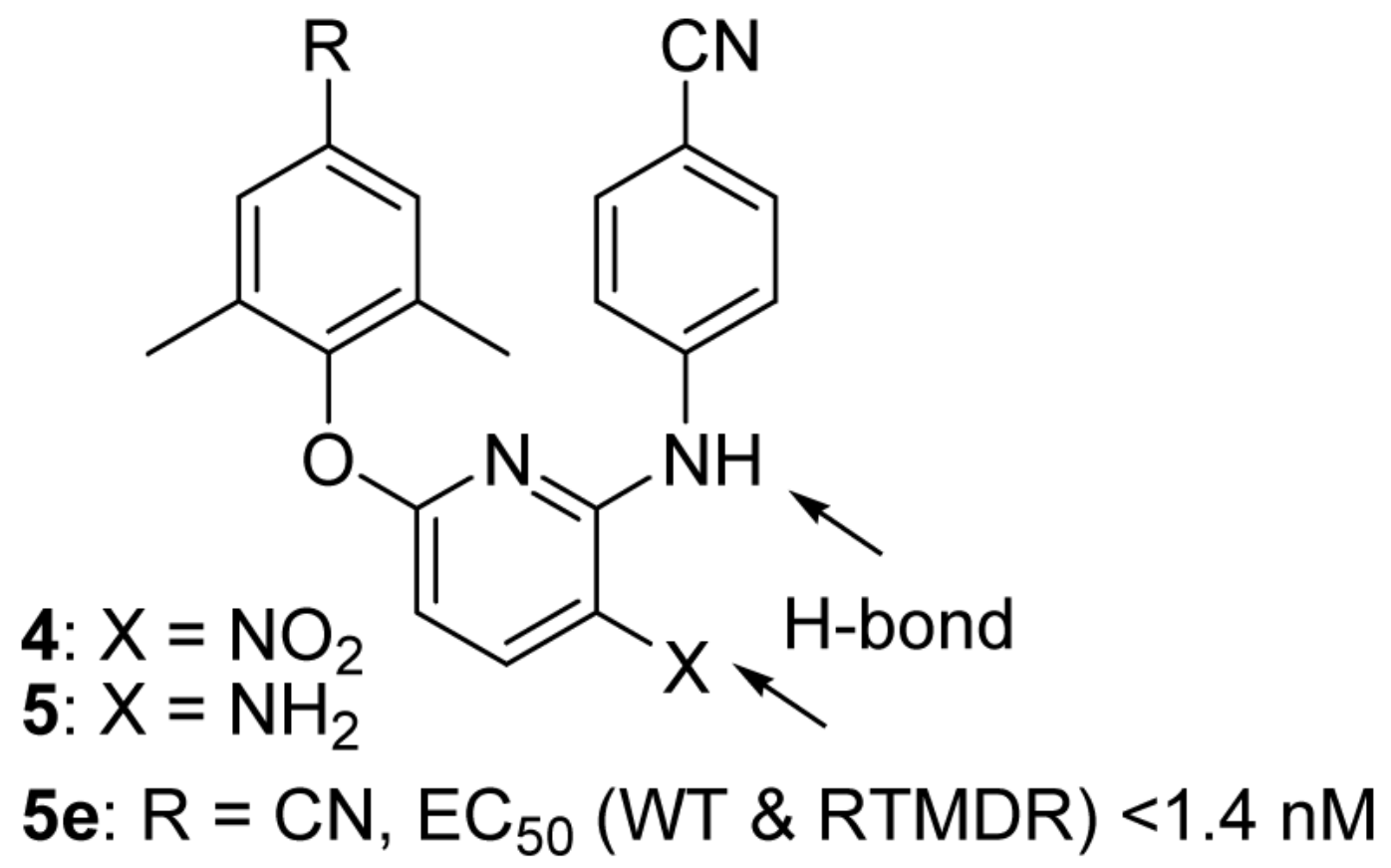

\section{Keywords}

diarylpyridine derivatives; HIV-1 NNRTIs; drug resistance

Reverse transcriptase (RT) is one of the most important enzymes in the HIV-1 life cycle. Two major drug target sites in the RT are the substrate binding site and an allosteric site that is distinct from, but closely located to, the substrate binding site. ${ }^{1,2,3}$ Non-nucleoside reverse transcriptase inhibitors (NNRTIs) interact with the allosteric binding site on HIV-1 RT to cause distortion of the three-dimensional structure of the enzyme and to inhibit RT catalytic function. Currently,NNRTIs approved for AIDS therapy include nevirapine, delavirdine, efavirenz, and etravirine (TMC125). TMC125, ${ }^{4} \mathrm{TMC} 120,{ }^{5}$ a previous clinical candidate, and TMC278, ${ }^{6}$ a promising new drug candidate in phase III clinical trial, (Fig 1) are compounds belonging to the diarylpyrimidine (DAPY) family. ${ }^{7}$ These compounds are very potent against both wildtype and many drug-resistant HIV-1 strains. The excellent pharmacological profile of these compounds has encouraged new research to explore a next-generation of NNRTIs with new scaffolds. Prior studies on DAPY derivatives have revealed some pharmacophores, ${ }^{1,8}$ such as a horseshoe binding conformation, a proper positioning of two phenyl rings in the eastern and western wings of the NNRT binding pockets, a para-cyanoaniline moiety in the eastern wing, and two hydrogen bonds to K101 of HIV-1 RT. Based on this SAR information, we initiated a program to explore new NNRTI leads with new molecular scaffolds and high potency against wild-type and drug-resistant viral strains. By using an isosteric replacement strategy, diarylpyridine compounds were designed, synthesized, and evaluated for anti-HIV-1 activity. Among the tested compounds, new active leads with high potency against both wild-type and drug-resistant HIV-1 strains were discovered. We report our promising results herein.

Compared to TMC125, our target compounds (Figure 1) were designed to retain the active para-cyanoaniline moiety, but have a pyridine replacing the pyrimidine ring and various substituents at the para-position of the phenoxy ring. Because the isosteric replacement of pyridine for pyrimidine should not change the molecular topology or flexibility, we 
hypothesized that the designed compounds would have similar binding orientation, conformation, and comparable activity to that of TMC125 and TMC278 ( $\mathrm{EC}_{50} / \mathrm{SI}$ : 0.00158 $\mu \mathrm{M} / 63,096$ and $0.0005 \mu \mathrm{M} / 60,000$, respectively, against HIV-1 ${ }_{\text {IIIB }}$ replication in the MT- 4 cell line), $,{ }^{9}, 10$ as well as TMC120. However, the substitution of pyridine for pyrimidine resulted in the loss of an H-bond between K101 and the second nitrogen on the pyrimidine ring. Therefore, we incorporated a nitro or amino group at the 3-position on the pyridine ring to provide potential $\mathrm{H}$-bonding with $\mathrm{K} 101$, as either an H-bond acceptor or donor.

The target compounds were synthesized via the short routes detailed in Schemes 1 and 2 . The starting material 2,6-dichloro-3-nitropyridine (1) is inexpensive and commercially available. Reacting 1 with 4-aminobenzonitrile (2) at $140{ }^{\circ} \mathrm{C}$ provided 4-(6-chloro-3-nitropyridin-2ylamino)benzonitrile (3). Compound $\mathbf{3}$ was coupled with a substituted phenol in DMF in the presence of potassium carbonate at $120^{\circ} \mathrm{C}$ for $6 \mathrm{~h}$ to afford the target compounds 4a-e. Compound $\mathbf{4 f}$ was prepared by Sonogashira coupling ${ }^{11}$ between $\mathbf{4 d}$ and 2-methyl-3-butyn-2ol in DMF catalyzed by palladium-copper, and was then refluxed in dry toluene in the presence of powdered sodium hydroxide to provide $\mathbf{4 g}$ (Scheme 2). Finally, the nitro group on the pyridine ring in $\mathbf{4 a - 4 g}$ was reduced to an amino group by using sodium hydrosulfite dehydrate $^{12}$ to afford 5a-5g, respectively (Scheme 1). The spectroscopic data of the 14 target compounds were consistent with the structures shown in Scheme $1 .{ }^{13}$

The inhibitory activity of nitro-diarylpyridine (4a-4g) and amino-diarylpyridine (5a-5g) derivatives on HIV-1 IIIB replication in MT-2 cells and cytotoxicity against MT-2 cells were determined as previously described. ${ }^{14}$ As shown in Table 1 , except for $\mathbf{4 f}$, most nitrosubstituted compounds (series 4 ) showed significant inhibitory activity against HIV-1 replication $\left(\mathrm{EC}_{50} 0.12-2.4 \mu \mathrm{M}\right)$ and low cytotoxicity $\left(\mathrm{CC}_{50} 50-503 \mu \mathrm{M}\right)$, resulting in selectivity index (SI) values of 61 to 4,264. All the amino-substituted compounds (series 5) displayed greater anti-HIV-1 IIIB activity $\left(\mathrm{EC}_{50} 0.001-1.58 \mu \mathrm{M}\right)$ than the corresponding compounds in series $\mathbf{4}$. However, the series 5 compounds were also more cytotoxic $\left(\mathrm{CC}_{50} 2.19\right.$ $-31.78 \mu \mathrm{M})$ than the corresponding series 4 compounds. With an SI of 22,700, the most promising compound was $\mathbf{5 e}$.

All target compounds were further tested against HIV-1 NL4-3 and a drug resistant strain HIV-1 RTMDR1, in comparison with TMC120 (Table 2). In agreement with the MT-2 data, 5e was also the most active compound and had the highest SI $(13,162)$ against NL4-3. The potency of $\mathbf{5 e}$ in this assay was comparable to that of TMC120. Interestingly, the active compounds in both series $\mathbf{4}$ and $\mathbf{5}$ showed similar inhibitory potency against NL4-3 and RTMDR1, which is resistant to many NRTIs and NNRTIs. ${ }^{15}$ The most potent compound, $\mathbf{5 e}$, had an $\mathrm{EC}_{50}$ value of $0.96 \mathrm{nM}$ against HIV-1 RTMDR1 and $0.68 \mathrm{nM}$ against HIV-1 NL4-3, a difference of only 1.4-fold. These results suggested that the pyridine ring is an acceptable moiety to replace the pyrimidine ring of DAPY compounds and an amino group at the 3position of the pyridine ring enhances anti-HIV activity against both wild-type (IIIB and NL4-3) and multidrug resistant (RTMDR1) HIV-1 strains.

Similar to TMC125, the most active new compound, 5e, has a para-cyano group on the phenoxy ring. Compounds with methyl, hydroxymethyl, ethynyl, iodo, and no para-substituent were also active. However, compounds $\mathbf{4 f}$ and $\mathbf{5 f}$ with a bulky 2-methylbut-3-yn-2-ol $[\mathrm{C} \equiv \mathrm{C} \mathrm{C}(\mathrm{OH})$ $\mathrm{Me}_{2}$ ] group at the para-position of the phenoxy ring lost anti-HIV potency, although $\mathbf{4 g}$ and $\mathbf{5 g}$ with only a simple ethynyl substituent were active. These results suggested that substituents at this position of the phenoxy ring also directly affect anti-HIV potency, and a bulky group might not fit well into the hydrophobic cleft on the west wing of the NNRTI binding site. ${ }^{16}$

In summary, two series (4 and $\mathbf{5}$ ) of diarylpyridine derivatives were designed, synthesized, and evaluated for anti-HIV-1 activity, resulting in the discovery of a new class of NNRTI leads, 
diarylpyridine-3-amine derivatives $(\mathbf{5 a}-\mathbf{5 e}, \mathbf{5 g})$, with highly potent anti-HIV-1 activity against both RTI-sensitive (IIIB and NL4-3) and -resistant (RTMDR1) HIV-1 strains. The most promising compound was 5e, which inhibited HIV-1 IIIB, NL4-3, and RTMDR1 with low $\mathrm{nM} \mathrm{EC}_{50}$ values. The results of this study indicated that diarylpyridine could be used as a novel scaffold to derive a new class of potent NNRTIs with activity against both wild-type and drug resistant HIV-1 strains. In addition, the pyridine ring replacement provides a more convenient and shorter synthetic route, using inexpensive commercial reagents, compared to the synthesis of DAPYderivatives TMC125 and TMC278. ${ }^{17,10}$ Our current preliminary structure-activity relationship (SAR) studies have revealed that (1) the pyridine is an acceptable isosteric replacement for the pyrimidine ring in DAPY derivatives, (2) an amino group at the 3-position on the pyridine is crucial for enhancing anti-HIV activity, and (3) the R group on the phenoxy ring is also an important moiety affecting anti-HIV activity. In light of the promising anti-HIV-1 activity of the diarylpyridine derivatives, further structural optimization is likely to yield novel NNRTIs with greatly improved potency.

\section{Acknowledgments}

This investigation was supported by grants 20472114 and 7052057 from the National Natural Science Foundation of China and Beijing government, respectively, awarded to L. Xie, as well as NIH grants AI46221 to S. Jiang, AI33066 to K. H. Lee, and AI65310 to C. H. Chen

\section{References and notes}

1. De Corte BL. J. Med. Chem 2005;48:1689. [PubMed: 15771411]

2. Tantillo C. J. Mol. Biol 1994;243:369. [PubMed: 7525966]

3. Pauwels R. Curr. Opin. Pharmacol 2004;4:437. [PubMed: 15351347]

4. Andries K, Azijn H, Thielemans T, Ludovici D, Kukla M, Heeres J, Janssen P, De Corte B, Vingerhoets J, Pauwels R, de Be'thuneet MP. Antimicrobl Agents and Chemother 2004;48(12):4680.

5. Gruzdev, B.; Horban, A.; Boron-Kaczmarska, A.; Gille, D.; Van't Klooster, G.; Pauwels, R. 8th Conference on Retroviruses and Opportunistic Infections; Chicago, IL. February 4-8, 2001; Abstr. 13

6. De Clercq E. Int. J. Antimicrob. Agents 2009;33:307. [PubMed: 19108994]

7. Janssen PAJ, Lewi PJ, Arnold E, Daeyaert F, de Jonge M, Heeres J, Koymans L, Vinkers M, Guillemont J, Pasquier E, Kukla M, Ludovici D, Andries K, de Bethune MP, Pauwels R, Das K, Clark AD, Frenkel YV, Hughes SH, Medaer B, De Knaep F, Bohets H, De Clerck F, Lampo A, Williams P, Stoffels P. J. Med. Chem 2005;48:1901. [PubMed: 15771434]

8. Das K, Lewi PJ, Hughes SH, Arnold E. Prog. Biophys. Mol. Biol 2005;88:209. [PubMed: 15572156]

9. Van Herrewege Y, Vanham G, Michiels J, Fransen K, Kestens L, Andries K, Janssen P, Lewi P. Antimicrob. Agents Chemother 2004;48:3684. [PubMed: 15388420]

10. Guillemont J, Pasquier E, Palandjian P, Vernier D, Gaurrand S, Lewi PJ, Heeres J, de Jonge MR, Koymans LMH, Daeyaert FFD, Vinkers MH, Arnold E, Das K, Pauwels R, Andries K, de Bethune MP, Bettens E, Hertogs K, Wigerinck P, Timmerman P, Janssen PAJ. J. Med. Chem 2005;48:2072. [PubMed: 15771449]

11. Rodriguez JG, Tejedor JL, La Parra T, Diaz C. Tetrahedron 2006;62:3355.

12. Redemann CT, Redemann CE. Org. Synth 1949;29:8.

13.

14. Xie L, Guo HF, Lu H, Zhuang XM, Zhang AM, Wu G, Ruan JX, Zhou T, Yu D, Qian K, Lee KH, Jiang S. J. Med. Chem 2008;51:7689. [PubMed: 19053755]

15. Larder BA, Kellam P, Kemp SD. Nature 1993;365:451. [PubMed: 7692302]

16. Das K, Bauman JD, Clark AD, Frenkel YV, Lewi PJ, Shatkin AJ, Hughes SH, Arnold E. Proc. Natl. Acad. Sci. USA 2008;105:1466. [PubMed: 18230722]

17. Ludovici DW, De Corte BL, Kukla MJ, Ye H, Ho CY, Lichtenstein MA, Kavash RW, Andries K, de Bethune MP, Azijn H, Pauwels R, Lewi PJ, Heeres J, Koymans LMH, de Jonge MR, Van Aken KJA, 
Daeyaert FFD, Das K, Arnold E, Janssen PAJ. Bioorg. Med. Chem. Lett 2001;11:2235. [PubMed: 11527705] 
<smiles></smiles>

TMC125, etravirine<smiles>[R]c1cc(C)c(Nc2ccnc(Nc3ccc(C#N)cc3)n2)c(C)c1</smiles>

TMC120, $\mathrm{R}^{1}=\mathrm{CH}_{3}$ $\mathrm{TMC278}, \mathrm{R}^{1}=\mathrm{CH}=\mathrm{CHCN}$<smiles>[X][X]c1ccc(Oc2c(C)cc([R])cc2C)nc1Nc1ccc(C#N)cc1</smiles>
Target compounds

Figure 1.

TMC125, TMC120, TMC278, and target compounds. 


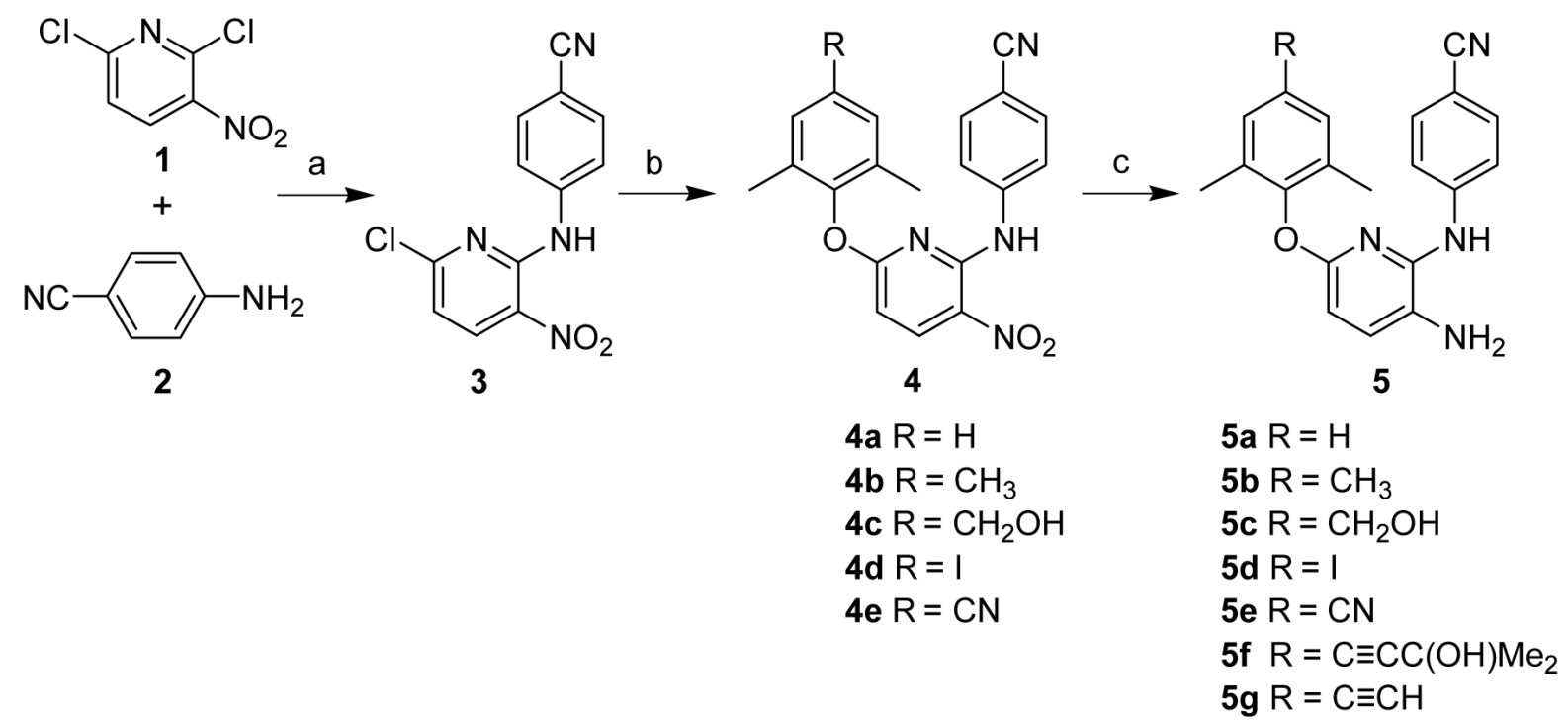

Scheme 1.

(a) $140{ }^{\circ} \mathrm{C}, 4 \mathrm{~h}, \mathrm{~N}_{2}, 73 \%$; (b) substituted phenol, $\mathrm{K}_{2} \mathrm{CO}_{3}, \mathrm{DMF}, 120{ }^{\circ} \mathrm{C}, 6 \mathrm{~h}, 65-82 \%$; (c) $\mathrm{Na}_{2} \mathrm{~S}_{2} \mathrm{O}_{4}, \mathrm{NH}_{3} \cdot \mathrm{H}_{2} \mathrm{O}, \mathrm{THF} / \mathrm{H}_{2} \mathrm{O}=1 / 1(\mathrm{v} / \mathrm{v}), \mathrm{rt}, 3 \mathrm{~h}, 41-70 \%$. 


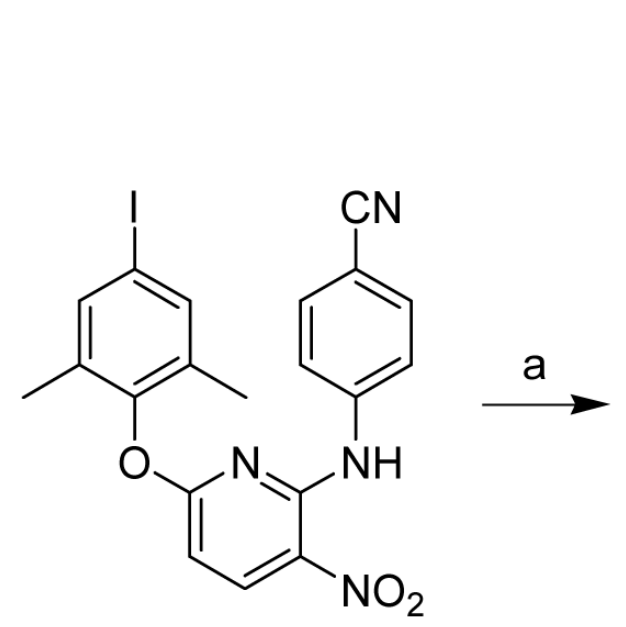

4d<smiles>Cc1cc(C#CC(C)(C)O)cc(C)c1Oc1ccc([N+](=O)[O-])c(Nc2ccc(C#N)cc2)n1</smiles>

$4 f$<smiles>C#Cc1cc(C)c(Oc2ccc([N+](=O)[O-])c(Nc3ccc(C#N)cc3)n2)c(C)c1</smiles>

4g

Scheme 2.

(a) 2-methyl-3-butyn-2-ol, $\mathrm{Pd}\left(\mathrm{PPh}_{3}\right)_{2} \mathrm{Cl}_{2}, \mathrm{Et}_{3} \mathrm{~N}, \mathrm{CuI}, \mathrm{DMF}, \mathrm{N}_{2}, \mathrm{rt}, 7$ h, 78\%; (b) $\mathrm{NaOH}$, toluene, reflux, $16 \mathrm{~h}, 69 \%$. 
Table 1

Inhibitory activity of $\mathbf{4 a - 4 g}$ and $\mathbf{5 a - 5}$ on HIV-1 ${ }_{\text {IIIB }}$ replication in MT-2 cells ${ }^{a}$

\begin{tabular}{cllll}
\hline Compds & $\mathbf{R}$ & $\mathbf{C C}_{\mathbf{5 0}}(\boldsymbol{\mu M}) \boldsymbol{b}$ & $\mathbf{E C}_{\mathbf{5 0}}(\boldsymbol{\mu M})^{\boldsymbol{c}}$ & $\mathbf{S I}^{\boldsymbol{d}}$ \\
\hline $\mathbf{4 a}$ & $\mathrm{H}$ & $110.2 \pm 0.0$ & $1.028 \pm 0.139$ & 107 \\
$\mathbf{4 b}$ & $\mathrm{CH}_{3}$ & $503.2 \pm 5.2$ & $0.118 \pm 0.053$ & 4,264 \\
$\mathbf{4 c}$ & $\mathrm{CH}_{2} \mathrm{OH}$ & $115.8 \pm 14.1$ & $0.192 \pm 0.005$ & 603 \\
$\mathbf{4 d}$ & $\mathrm{I}$ & $148.5 \pm 31.2$ & $2.428 \pm 0.309$ & 371 \\
$\mathbf{4 e}$ & $\mathrm{CN}$ & $50.13 \pm 2.60$ & $0.135 \pm 0.286$ & 21 \\
$\mathbf{4 f}$ & $\mathrm{C} \equiv \mathrm{CC}(\mathrm{OH}) \mathrm{Me}_{2}$ & $8.91 \pm 0.0$ & $23.28 \pm 10.48$ & 256 \\
$\mathbf{4 g}$ & $\mathrm{C} \equiv \mathrm{CH}$ & $173.6 \pm 46.0$ & $0.677 \pm 0.286$ & 182 \\
$\mathbf{5 a}$ & $\mathrm{H}$ & $29.9 \pm 2.3$ & $0.576 \pm 0.182$ & 391 \\
$\mathbf{5 b}$ & $\mathrm{CH}$ & $10.55 \pm 0.41$ & $0.058 \pm 0.026$ & 297 \\
$\mathbf{5 c}$ & $\mathrm{CH} \mathrm{H}_{2} \mathrm{OH}$ & $2.19 \pm 0.41$ & $0.006 \pm 0.002$ & 22,700 \\
$\mathbf{5 d}$ & $\mathrm{I}$ & $23.49 \pm 5.77$ & $0.079 \pm 0.007$ & 2 \\
$\mathbf{5 e}$ & $\mathrm{CN}$ & $31.78 \pm 10.37$ & $0.0014 \pm 0.0023$ & 20 \\
$\mathbf{5 f}$ & $\mathrm{C} \equiv \mathrm{CC}(\mathrm{OH}) \mathrm{Me}_{2}$ & $3.54 \pm 1.07$ & $1.578 \pm 0.097$ & $0.424 \pm 0.282$ \\
$\mathbf{5 g}$ & $\mathrm{C} \equiv \mathrm{CH}$ & $8.25 \pm 0.51$ & & \\
\hline
\end{tabular}

${ }^{a}$ Compounds were tested in triplicate and the data are presented as means \pm SD.

${ }^{b}$ XTT assay was used to determine the $50 \%$ cytotoxic concentration $\left(\mathrm{CC}_{50}\right)$.

${ }^{c}$ ELISA was used to determine p24 production, based on which the 50\% effective concentration (EC50) for inhibiting HIV-1 replication was calculated.

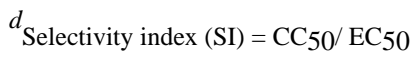




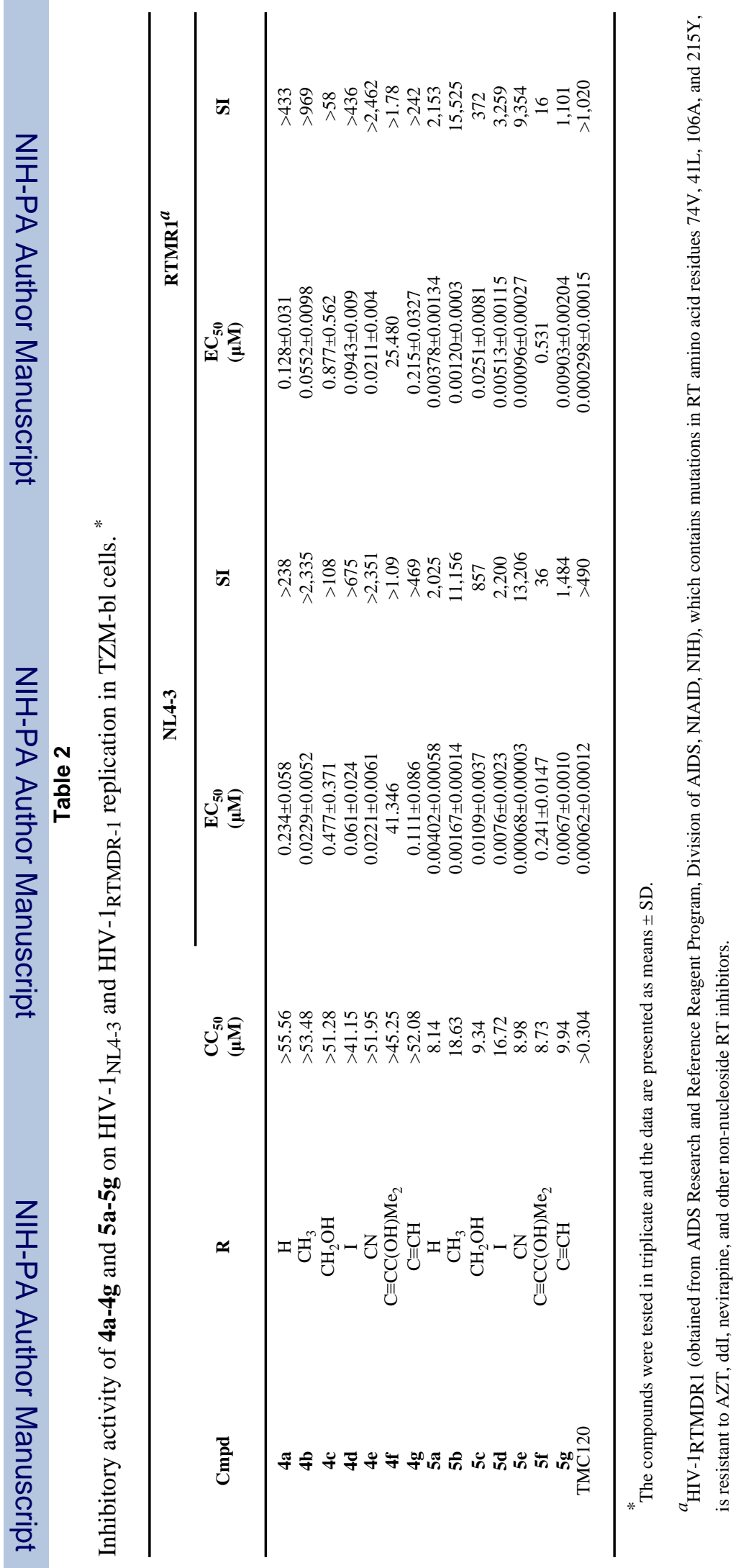

